\title{
軟ろうの濡れ易さと接触角についで*
}

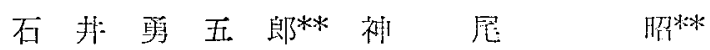

\section{On Wettability and Contact Angle of Soft Solder*}

\author{
By Y. Ishii** and A. Kannö**
}

\begin{abstract}
Contact angle is an important factor which influences wettability of brazing alloy to base metal. Relation between wettability and contact angle was examined in this paper. Brazing alloys were set upon the horizontal base metal plates in vacuum as the first method. After brazing alloys were melted, the shapes of alloys spreading over base metals were photographed in phorizontal direction. Alloys which have eutectic point in their diagrams, such as $\mathrm{Sn}-\mathrm{Pb}$ and $\mathrm{Sn}-\mathrm{Bi}$, have minimum contact angle to $\mathrm{Cu}$ at the composition a little nearer to $\mathrm{Sn}$ than eutectic. Alloys having nonmetalic element such as $\mathrm{P}$, As have very small contact angles. Contact angle also decreases when alloy have small amount of base metal element.

As second method, following experiment was done. Slitts, composed of parallel base metal plates, were preheated in soldering flux. After holding them several miniutes at test temperature, the slitts were inserted vertically into molton brazing alloy under flux. Hights of the capillary rises and contact angles wera measured from X-ray radiographs. Contact angles and their decreases with temperature rise were very small in flux compared to in vacuum. It was obtained from the shape of sessile drop that surface tension of $\mathrm{Sn}$ in $\mathrm{ZnCl}_{2}$ at $300^{\circ} \mathrm{C}$ was smaller than in vacuum about $30 \%$. Hight of capillary rise increases with test temperature increasing. Though this phenomenon is considered largely due to decrease of contact angle, authers could not determine it with X-ray radiographs.
\end{abstract}

緒言

るう接に括いては固体金属と液体金属問に複雑な現象が 起るが，固体金属に熔融るう材が如何に濡れ搪っていくか という点てついて，主として観祭してみた．まず第一の方 法として，真空中に水平保った母材金属板上でろう材を 加熱熔融し，この接触角の変化する様子をカメラで撮影し た. 第二の方法として平行な母材金属スリット中を上昇す るろう材の高さで，これらろう材の濡れ易さを比較し，併 ぬて熔融金属中に母材を金直飞挿大した場合の母材とろう 材の䦬の接触角の变化を観察した，第二の方法では金属の 酸化を防ぎまた既存の酸化物を除去し，さら飞試駼片を子 熱する目的で溶剂を用いたので，母材，ろう材の組成，温

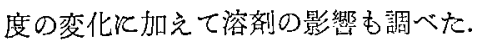

\section{1 真空中における接解角の変化}

ろろ材が水平汇置かれた母材金嘚板上で揢融して搪る場 合, 接触角, ろう材の表面張力, 密度の関係を考兄て見 る. 、ま液滴の頂部が大体直線とみなされ，また水平断面 の曲率が無視できる場合, Fig. 1 の如く溥いかまぼこ状に

* 原稿受付 昭和 33 年 2 月 5 日（昭和 32 年度签接学会 秋季学術講演会江招いて発表)

** 正員, 運輸技術研觉所 Member, Transportation Technical Research Institute.

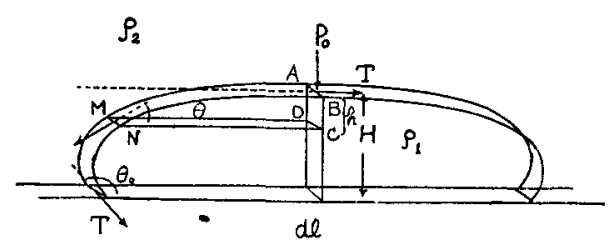

Fig. 1 Shape of sessile drop and its relating factors; surface tenston $T$, contact angle $\theta_{0}$, density of brazing alloy $\rho_{1}$, density of flux $\rho_{2}$.

切出したもの」中，さらに ABCNMD で用まれた部分の 釣合を考学る， $\mathrm{ABCD}$ ほ液頂部に括引る重直面， $\mathrm{MNCD}$ は水平面である，乙の部分は出面 ABNM そ加わる溶剂飞 よる正力, 表面張力の水平分力と $\mathrm{ABCD}$ 《加わる液压が 釣合っているとして次の式が求められる.

$$
\begin{aligned}
& \int_{0}^{h} P_{0} d l d h+\int_{0}^{h} \rho_{2} g h d l d h-T \cos \theta \cdot d l+T d l \\
& =\int_{0}^{h} \rho_{1} g h d l d h+\int_{0}^{h} P_{0} d l d h
\end{aligned}
$$

より

$$
T(1-\cos \theta)=\frac{1}{2} \cdot\left(\rho_{1}-\rho_{2}\right) g h^{2}
$$

$\int_{0}^{h} P_{0} d l d h+\int_{0}^{h} \rho_{2} g h d l d h$ \&溶剂の曲面 ABNM 飞加わる生 力, $\int_{0}^{h} P_{0} d l d h$ は液頂部に特ける溶剂の $\mathrm{ABCD}$ 飞加わる 圧力で $\theta$ は図の如く表面張力 $T$ と水平面のなす角度で 
ある.こ১で $T$ は溶剂中に拈けるろう剂の表面張力であ る. $\theta$ が接触角 $\theta_{0}$ 飞極めて近いところでもこの関係は成 立つと考光られるから，液頂の高さを $H$ とすると

$$
T\left(1-\cos \theta_{0}\right)=\frac{1}{2}\left(\rho_{1}-\rho_{2}\right) g H^{2}
$$

が成立つ. 真空中では $\rho_{2}=0$ になる. これは接触角と液滴 の高さの関係を示している. 液滴の体積が一定であるとき は接触角が小さくなり, それに応じて $H$ が小さくなって 液滴の拡る面積が大きくなり, ろう材はよく拡延する。例 えばこの式が適用できる状態で，ろう材が同じで母材が異 る場合は $T$ が一定で接触角が異る。いま接触角が $90^{\circ} の$ ときろう材と母材の間の接触面積を $S_{90}, 45^{\circ}$ のときを $S_{45}$ とする. $H$ を $90^{\circ}$ のきの液滴の高さとし， $45^{\circ}$ そなって $\Delta H$ 減少すると次の式が成立つ.

$$
\begin{aligned}
S_{45} & \doteqdot S_{90}+S_{90} \cdot \frac{\Delta H}{H-\Delta H} \\
& =1.85 S_{90}
\end{aligned}
$$

このようと接触角はろう材の濡れ拡り易さを定める重要 な因子であり,こ」では真空中, 各温度, 組成に対する接 触角を測定した.

(1) 実 験 方 法

Fig. 2 と示すように長さ $50 \mathrm{~cm}$ 内径 $3 \mathrm{~cm}$ の石英管の

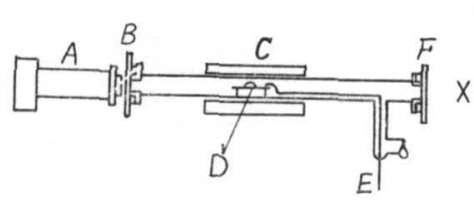

Fig. 2 Measuring squipment of contact angle in vacuum
A Camera
B Glass window
C Electric resistance furnace
D Specimen
E Thermo-couple
F Flosted glass window
$\mathrm{X}$ Light source

一端を曇りガラ

スで，他端を透

明ガラス板で気

密を保つょうに し, 一端に近い 枝管から空気を 抜いて $10^{-4} \mathrm{~mm}$ $\mathrm{Hg}$ 程度の真空 にした. 管の中 央部にある石英 台上に母材を置 き，これを水平 飞保つ.この上

飞大体 $6 \mathrm{~mm}$ 立方飞切出したろろ材をのせる. 母材は土 ミリーF1 で研磨しペンゼンで脱脂してある. 晨りガラ ス端の外側で電灯をつけ，熔融ろう材の影を透明なガラス を透して実物大の大きさに $35 \mathrm{~mm}$ カメラで撮影した.る う材は熔融して偏平球状になる。年の後速か飞測定温度ま で上げ，接触角が変化して平衡飞達する，その状態を Phot. 1 飞示した. 撮影したフィルムは 5 倍に引伸して接 触角を測った. 測定䛊差は接触角の大なるところでは士5 で, $110^{\circ}$ 以下 $40^{\circ}$ 位までの角度では $\pm 2^{\circ}$ である. 真空 中で金属を熔融すると，その中飞含まれるガスによって体 積が增大することがあるが，接触角に及ぼす影響はない.

(2) 実 験 結 果

\section{Photo. 1}

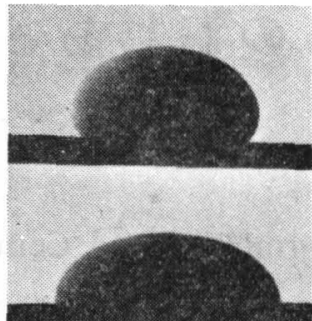

1 minutes

Decrease of contact angle to equilibrium

2 minutes

Brazing alloy $\mathrm{Sn}-\mathrm{Sb}$ (10\%) Base metal Cu

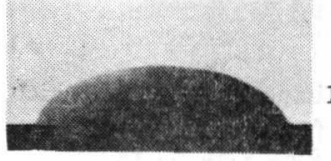

10 minutes

a 平衡飞達する時間

ろう材が母材上で熔融してから速かに測定温度まで上昇 させ, この温度に達してからの接触角の時間的変化を測っ た. 母材上にろう材が置かれているため測定時間の小さい 所はそれまでそ経過した各温度の影響が多いので, 測定值 は測定温度に達して 2 分経過後から示してある.

Fig. 3 は $\mathrm{Cu}$ に対し, $\mathrm{Sn}-\mathrm{Bi}$ 合金が $400^{\circ} \mathrm{C}$ で濡れる場 合である.

$\mathrm{Bi}$ は $\mathrm{Sn}$ 共晶を作る 金属であ りまた $\mathrm{Cu}$ とも共晶を 作るが，Sn のみの場合 より平衡飞 達する時間 が早くな る. 接触角 山大体10分 で平衡に達 した. 他の 温度抏よび 合金でも大 体10分で平 衡汇達し た.

b ろう材 と母材の 組成と接 触角

ろう材飞 $\mathrm{Sn}-\mathrm{Pb}$ 合 金, 母材飞

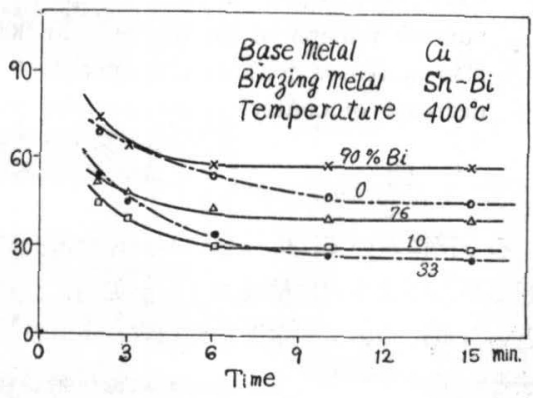

Fig. 3 Relation between contact angle and holding time

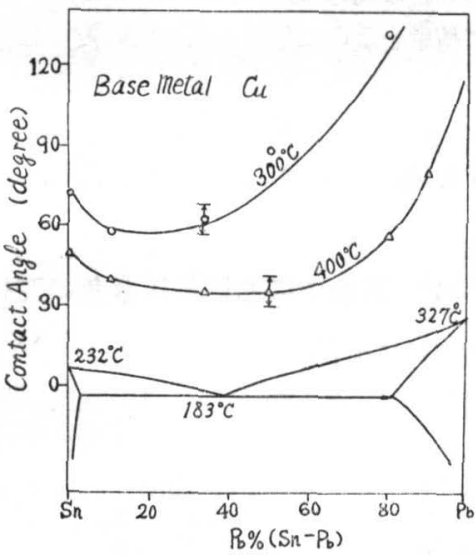

Fig. 4 Relation between composition of $\mathrm{Sn}-\mathrm{Pb}$ alloy and contact angle. Base metal $\mathrm{Cu}$ 
$\mathrm{Cu}$ を用いて各組成について平衡の接螌角を求めたものを Fig. 4 に示した. 平衡状態の接触角として，Fig. 3 の結 果より10分に剅值をとってある. Sn-Bi 合金について 同様に母材に Cu を用いて調べたものが Fig. 5 である.

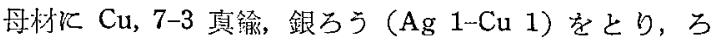
う材火Snをとって接触角を测ったものを Fig. 6 に示 す.銀ううは小さい接触角に速かに達する.

\section{c 温度の影響}

母材 $\mathfrak{C u}$ をとり，ろう材飞 $\mathrm{Sn}-\mathrm{Bi}$ 合金をとって接触 角の温度による变化を測ったのが Fig. 7 である. 図に見 る如く温度上昇飞伴って急激に平衡の接触角は減少してい る. 真空中であるのでろう材から蒸発した金属の影響も多 少あると茩えられるが，实験前执よび後の $\mathrm{Cu} の$ 表面状態 は变化していない。

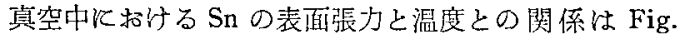
8 (詰1)の如く温度 $100^{\circ} \mathrm{C}$ 上昇により表面張力は大体 $2.5 \%$ 減少する，とのように温度上昇による表面張力の变化は極

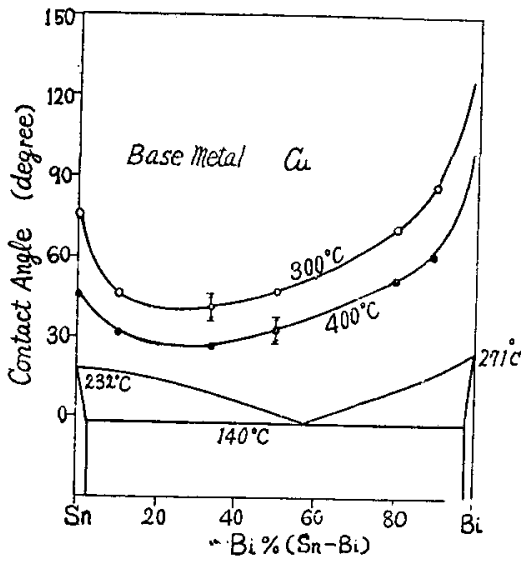

Fig. 5 Relation betwenn composition of $\mathrm{Sn}-\mathrm{Bi}$ alloy and contact angle. Base metal $\mathrm{Cu}$

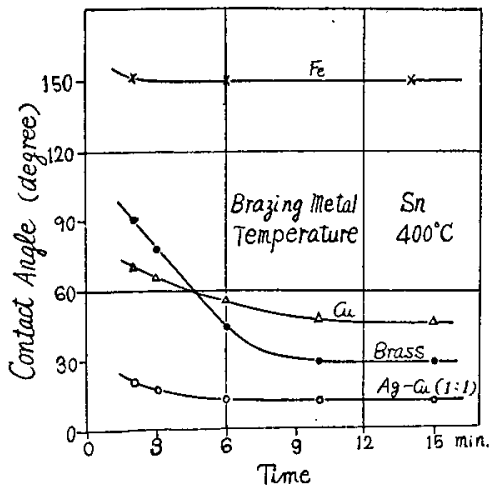

Fig. 6 Contact angle of $\mathrm{Sn}$ to various base metals; $\mathrm{Fe}, \mathrm{Cu}$, Brass, $\mathrm{Ag}-\mathrm{Cu}(1: 1)$.

めて少く，さら贯忉よりろう忉拡敬して表面張力が減 少することも少いと考它られるので，接触解の減少はるう 材の表面張力の減少《よるところは少いと考克られる.

d Sn K添加した各種元素の影憵

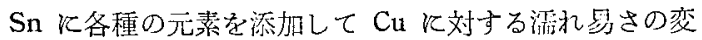

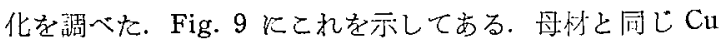

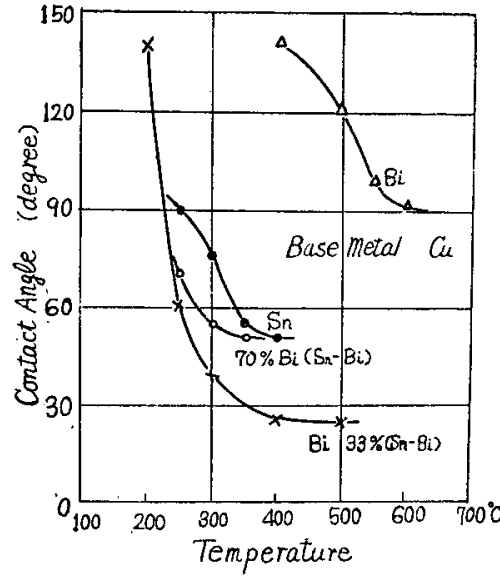

Fig. 7 Effect of temperature on contact angle. Brazing alloy $\mathrm{Sn}-\mathrm{Bi}$, base metal $\mathrm{Cu}$

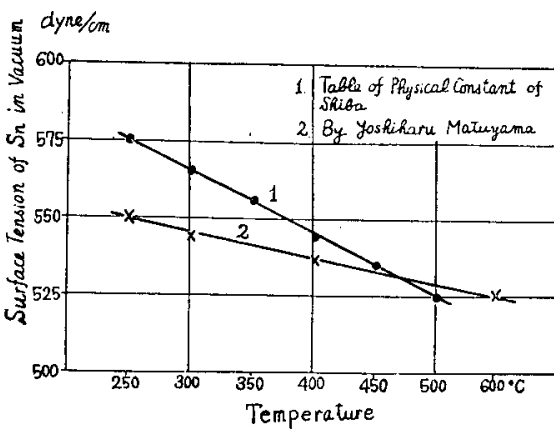

Fig. 8 Effect of temperature on surface tension of $\mathrm{Sn}$ in vacuum

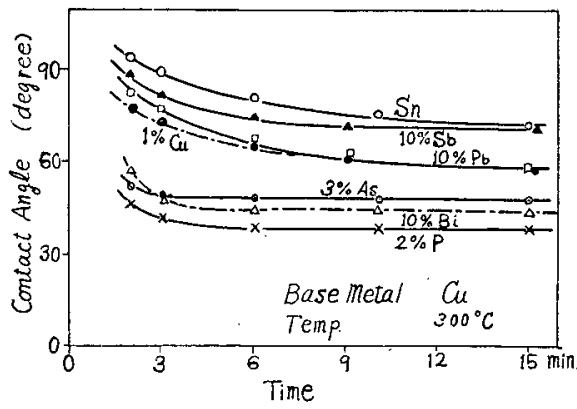

Fig. 9 Effect of various elements added to $\mathrm{Sn}$ on contact angle. Base metal $\mathrm{Cu}$. Temperature $300^{\circ} \mathrm{C}$
1\%年含も $\mathrm{Sn}$ は Snのみより 相当接触角が小 さくなる。また 韭金属元素を和 ずかに添加する 上接触角は小さ くなる As $3 \%$, $\mathrm{P} 2 \%$ 添加した それぞれのるう 材について，こ のことが認めら れる. Pについ てはとの性窅が 蒋しい。これ等

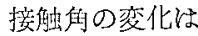
愦差籁国内の屯のもある が，大体の傾向学示すむ のと考光られる。

以上真空中心找的告 験であるが，この埼合に 恃熔融金属から出るガス によって母忉がわずかな からら鲐化するため，るう

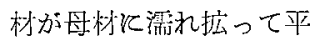
衡に逆する洔間が後に述 ベる溶剂中での㭙䦐より 長い。その平衡の接触角 もそれぞれ比較すると具 空中では溶剂中より少し 大きい。

\section{2 溶剂中のろう} 材の濡れ易さと 接解角

溶剂中《和いて接蚛角 と瀖れ易さの関係を調へ る目讪でこの䨑験を行。 た. Fig. 10 に示す上う 飞密度 $\rho_{1}$ の熔融 万う材 中平行板スリットを鉛 

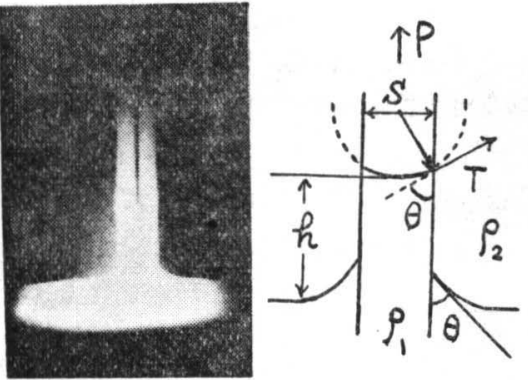

Fig. $10 \mathrm{X}$ ray photograph of capillary rise of brazing alloy in flux

直飞挿入する と, ろう材ね 毛管現象によ ってスリット 中を上昇し平 衡の高さ $h$ 飞 達する. $\rho_{2}$ は 溶剂の密度, $\theta$ はろう材と 母材の間の接 触角, $S$ はス リット間吵， $T$ は溶剂中のろう材の表面張力である. い まろう材が母材に濡れて接触角 $\theta$ をなして吸上げ曲線を 作るときとは細隙 $S$ に括いては液面は大体曲率半径 Rな る曲面をなし， $\frac{T}{R}$ なる負圧を生じて液を $h$ まで吸上げ る. とのX線写真を Fig. 10 と示した. このとき次の関 係がある.

$$
\begin{gathered}
P=\frac{T}{R}=\frac{2 T \cos \theta}{S}=\left(\rho_{1}-\rho_{2}\right) g h \\
h=\frac{2 T \cos \theta}{S\left(\rho_{1}-\rho_{2}\right) g}
\end{gathered}
$$

$S$ が一定で密度がほとんど変らない場合には $h$ を以って ろう材の濡れ易さを比較することができる. そして表面張 力 $T$ と接触角 $\theta$ が濡れ易さを定める因子である.

（1）実験 方 法

Fig. 11 に示す如く抵抗線電気炉を炉軸が垂直になるよ ろ飞置きそその中にあるルツボを押上げるととができるよ うになっている.ルツボは肉の薄い円壔形磁製ルツボを入 れる. 適当な量のろう材を入れて, その上に溶剂の粉末を

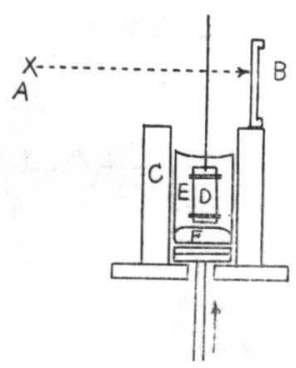

Fig. 11 Measuring equipment of capillary rise in flux

A Souce of $X$ ray

B X ray film

C Electric resistant furnace

D Specimen

E Flux

F Brazing metal
入れる. ルツボの内径はろう材 が溶解して作る液面が水平にな る程度の大きさが必要である. 溶剂とろう材が溶解後, 溶剂中 飞母材金属で作ったスリットを 中吊りにする. 電気炉の温度は トランスによって所定の温度に 維持される. 脱脂, 研磨された 試験片はこの間に予熱され，さ らと酸化物の除去も行われる.

所定温度に数分保った後, ルツ ボを押上げて炉外に出す。この とき試料も溶剂中に中吊りにな ったまっルツボと〉もに押上け られる. 中吊りの試料を垂直に ろう材中に浸け, 一定時間後ス リット方向から X線を送って後 方飞置かれたX線フイルムに影
絵の X 線写真を撮る.この間ルツボの中心部は冷却される ことなく所定温度に保たれている.ルツボは内径が大なる 方が望ましいが，透過 X線の透過度招よびコントラストの 問題のために余り大きくすることはできない.こ」では 径は $65 \mathrm{~mm}$ のルツボを使用した. 試験片は $2 \times 4 \mathrm{~cm}^{2}$, 厚さ 2〜 $5 \mathrm{~mm}$ の母材をエミナー F 1 で研磨しヘンンゼン で脱脂したもの〉間にピアノ線 $0.7 \mathrm{~mm}$ を細く切り四隅に 挾んでこれをニクロム線で縛った. スリットの間隙はシッ クネスゲージで測定し， $0.7 \pm 0.01 \mathrm{~mm}$ にした.

この実験においては試験片に温度勾配がないようにし て，ろう材が中途で温度が下り粘性が大きくなって上昇速 度が遅れて凝固することがないようにした。

使用したろう材は Snを主として，これと各種元素を添 加し, 組成については共晶組成に近いものを使用した. 母 材は電解鉄, $0.5 \mathrm{C} \%$ の炭素鋼, 電解銅, 7-3 真鍮につい て行った. 溶剂は有機化合物, 無機塩類ょよびそれらの混 合物があるが，有機化合物はルツボ中で沸騰して実験でき ないものが大部分である. 市販ぺーストは有機物を含み, $100^{\circ} \mathrm{C}$ に達すると沸騰して油煙を出し実際不可能であっ た. その他沸点のい塩化物も適当でない，この実験に衫い ては最も代表的な溶剂として塩化亜鉛を用いた. 塩化亜鉛 の融点は $260^{\circ} \mathrm{C}$ でこの実験には適していた.

(2) 実 験 結 果

\section{a ろう材の毛管上昇速さ}

ろう材と Snを用い,スリットを形成する母材として電 解鉄を用いて, $\mathrm{ZnCl}_{2}$ 溶剂中で毛管上昇により達する平衡

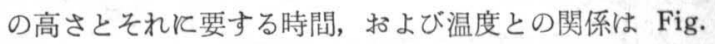
12 の如くなる. 試験片が完全に清浄な状態にあるときは, ろう材はほとんど瞬間的に上昇する. $400^{\circ} \mathrm{C}, 350^{\circ} \mathrm{C} て ゙ は$ $\mathrm{X}$ 線フイルムの感光にもある程度時間を要するので，4， 5 秒経過したところから測定可能であった. $300^{\circ} \mathrm{C}$ に挌い て曲線の上昇が少し 遅れているのは，ろ う材と溶剂の粘性に よるものと考えられ るが，30秒経過した ところでは完全に平 衡に達している.ろ う材が瞬間的飞上昇 することは，母材と ろう材間の合金の生 成, 相互拡散等飞よ る影響が少くなるの で都合がよい、これ は $\mathrm{Cu}$ 抽よび真鍮の ように Sn との合金 を作るものにも実験

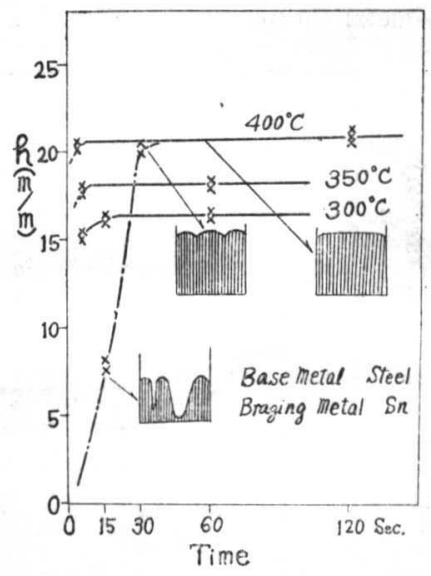

Fig. 12 Velocity of capillary rise 
を可能にした．銧線で示される曲線は表面が完全汇清浄に なっていない場合であって，このようなスりットを各時間 に取出して割って見ると, 初め両端と中央部にるう材の上 昇する柱ができ，この高さが平衙点洼してから横方向に 搪って平滑になるものが多かった。

\section{b 温度の影響}

ろう忉火 Sn, 母材飞電解鉄を用いて温度と上景する高 さ $h$ との哭係を求めたものを Fig. 13 亿示す。試験片は 測定温度で溶剂中で充分予熱され，ろう材中化一端を括入 してから 3 分経過捘 $\mathrm{X}$ 線 写真をとったので, 完全 に平衡の高さ涚してい るものと思われる。 Sn の融点は $232^{\circ} \mathrm{C}$ である が $\mathrm{ZnCl}_{2}$ が $260^{\circ} \mathrm{C}$ の融 点をむつので实験怯 $2 \varepsilon 0$ ${ }^{\circ} \mathrm{C}$ から可能であった. Fig. 13 火見る如く温度 上昇にともなって，らう 材の上昇する高さは急激 飞增大し， $450^{\circ} \mathrm{C}$ で最大 值飞值する，それ以上の 温度になると $\mathrm{ZnCl}_{2}$ の 分解が激しくなり Zn の

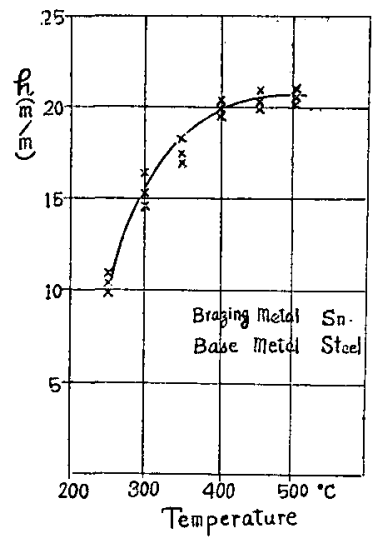

Fig. 13 Effect of temperature on capillary rise

析出が試料面隹認められ，汪とんどるう材が上昇しないこ ともある.このようなととす一因となって $450^{\circ} \mathrm{C}$ 以上でけ か兄って $h$ か隇少する，温度によって $h$ が增大する原因 として表面㖘力赫よび接触角の変化が考克られる.

\section{c 溶剂中の接触角执よび表面張力}

溶剂中のろう材の表面張力を測定するために，水平台上 溶剂中で溶融しているるう材の形状の X線写真をとり表面 張力を測定した. Fig. 14 亿括いて $\rho_{1}, \rho_{2}$ 快をれぞれるう 材 $\mathrm{Sn}$, 溶剤 $\mathrm{ZnCl}_{2}$ の $300^{\circ} \mathrm{C}$ K特ける密度, $T$ 性溶剂中

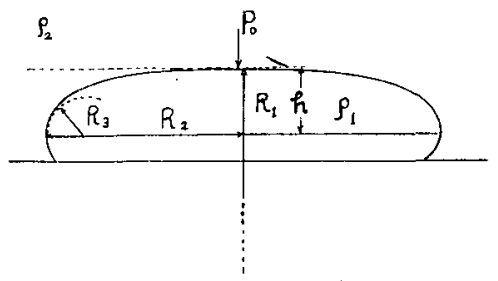

Fig 14 Schematic shape of sessile drop

の式から求められる。

$$
\begin{array}{r}
T\left(\frac{1}{R_{2}}+\frac{1}{R_{3}}\right)+P_{0}+\rho_{2} g h=\rho_{1} g h+\frac{2 T}{R_{1}}+P_{0} \\
T\left(\frac{1}{R_{2}}+\frac{1}{R_{3}}-\frac{2}{R_{1}}\right)=\left(\rho_{1}-\rho_{2}\right) g h
\end{array}
$$

$R_{1}=6.78 \mathrm{~cm} R_{2}=1.30 \mathrm{~cm} R_{3}=0.23 \mathrm{~cm} \rho_{1}-\rho_{2}=4.26 h=$ $0.45 \mathrm{~cm}$ より $T=384 \mathrm{dyne} / \mathrm{cm}$ 放求めた. 式(1)より $\theta=$ $90^{\circ}$ として求めると $430 \mathrm{dyne} / \mathrm{cm}$ を得たが曲率を考えた

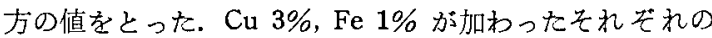
值むほとんど変化なかった，この值真空中の值より大体 30\%低い値である。

接触角を測定するにはX線写賣を用いた，Table 1 は熔

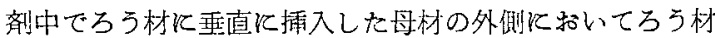
が引上げられて作った接触角を測ったものである。このと きるう材が作る曲線は次式で示される。(註1)

Table 1 Observed Contact Angle in Flux

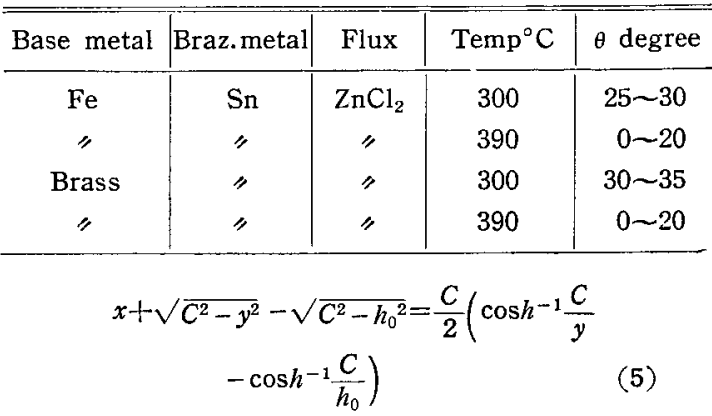

ろう材のなす水平面上母材面に直角飞 $x$ 軸, 母材表面上 鉛直方向飞 $y$ 朝, $C=2 \sqrt{T / \rho g} \rho=\rho_{1}-\rho_{2} \rho_{1}, \rho_{2}$ は $300^{\circ} \mathrm{C}$ 飞招什る Sn 扎よび $\mathrm{ZnCl}_{2}$ の密度 $h_{0}=C \sin \left(45^{\circ}-\frac{\theta}{2}\right)$ は $x=0$ に拓するろう材の引上げられた高さで・はそこ 飞括ける接触角である，先の測定結果より $T=384$ dyne/ $\mathrm{cm}$ をとった．式中 $h_{0}$ は接触角によって变る数値である ので，上述の表面張力，密度を有するるう材がそれぞれ 異った接触角に対してなす吸上曲線は Fig. 15 の如くにな る.この図でわかるよらに $\theta=0$ から $\theta=20^{\circ}$ 近くまでは 奏際の曲線についても判別は图晀であるが， $\theta=30^{\circ}$ 近傍 になるとその差が曲線炕現れて来る．とで(3) 式に $300^{\circ} \mathrm{C}$ 亿拉ける溶剂中の Sn の表面張力之接触角 $25^{\circ}$ の 值を入れて計算した值と Fig. 13 亿括ける $300^{\circ}$ の実測

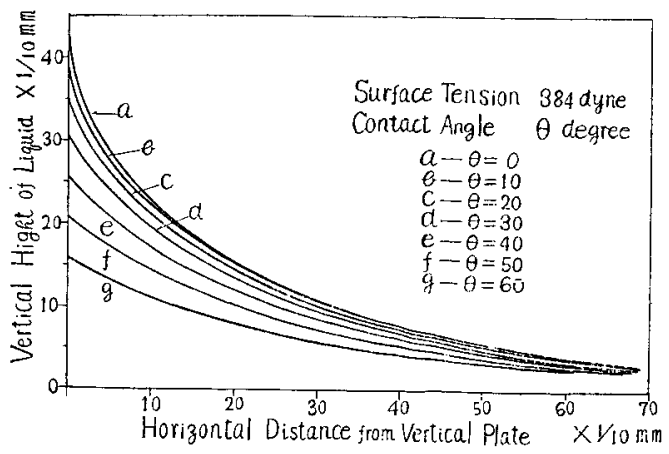

Fig. 15 Curve of capillary phenomenon at various contact angle 


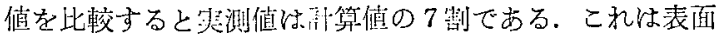
状態によって接出任が大きくなっているものと思われる.

\section{d 万弓材組成と瀖れ员さの此較}

毛留上早する高さは母材とろう忉の組合世によって変化

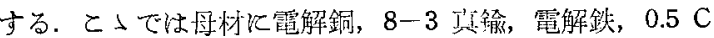

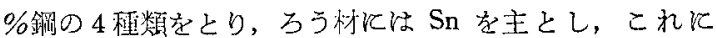
$\mathrm{Pb}, \mathrm{Zn}, \mathrm{Cd}$ を添加したもの，报よび $\mathrm{Cd}-\mathrm{Pb}$ 合金を用い

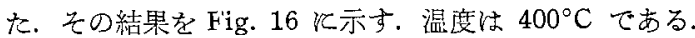

$\mathrm{Sn}$ 飞 $\mathrm{Pb}, \mathrm{Zn}$ を添加すると $h$ が $\mathrm{Sn}$ のみより下るのね

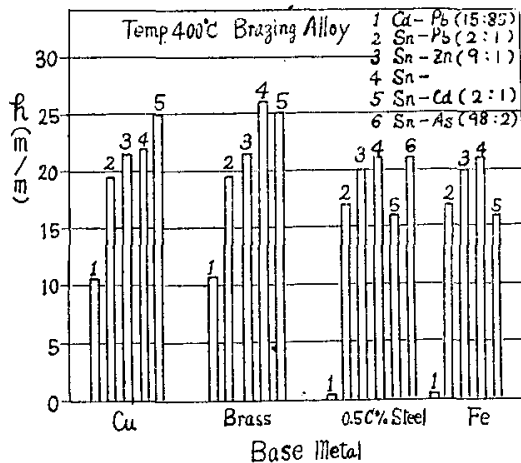

Fig. 16 Capillary rise of various brazing alloys $0.7 \mathrm{~mm}$ gap 4 種の时机 共通してい る. $\mathrm{Cu}$ と一 3 真鍮を比較 乙た埸含, Sn 忙 7-3 真鍮 刘ててよく 灀れている. これは蒖空中 に和ける接触 角が等鍮の方 が小さいのと 同じ傾问丞示 している.そ の他のろう合金は $\mathrm{Cd}-\mathrm{Pb}$ 合金も含めて, $\mathrm{Cu}$ と其鍷では

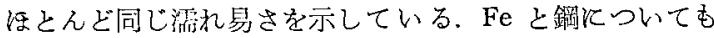
各ろう合金に対して同じ濡れ䀔さを示している. $\mathrm{Cd}-\mathrm{Pb}$ 合

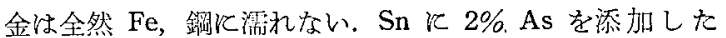
ものは其学中とは異りとの濡れ易い变化を示していない. $\mathrm{Cd}$ の添加恃 $\mathrm{Fe}$ ，鍓飞対しては $\mathrm{Sn}$ のの場会より相当 濡れ喤くなる。
結㣎

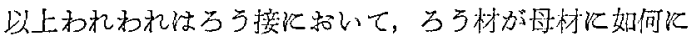

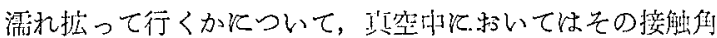

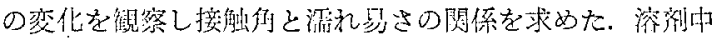

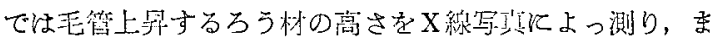
たその表面張力招よび接触俑在測った。

真空市飞招㳡る接触角の変化化ついては，母忉とろう材 の間《合金，共鼠，固溶するものは接触角が小さいこと， 温度が上显すると急激化接触角が小さくなり，るう材が母 材汇需れ帠いことを示している，P，Asのような非金您元 素を $2 ， 3 \%$ 添加したるう材は其空中では接触角が小さく なり母材とよく濡れる．溶剂中ではＡs を添加しても毛管 上昇行影㗽ななかった。

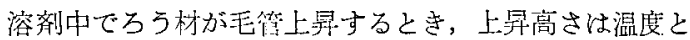
ょるに增し，最大值に達して後か党って下る．溶剂中の接 触角は具空中飞比して小さい，また温度仗よる変化も小さ

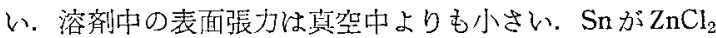
中 $300^{\circ} \mathrm{C}$ で熔融している場合，具空中上り約 $30 \%$ 減少し

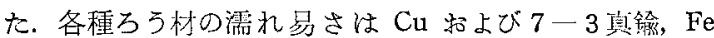
括よび $0.5 \mathrm{C} \%$ 鋼に対しそれでれ忹とんど同じであり，ま

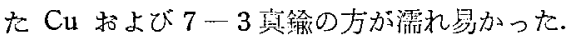

\section{文献}

詰（1） 1. 物理常数表（芝龟吉編）

2. On the Surface tension of molton metal and alloys. By Yoshiharu Matuyama-

-Science Reports of the Tohoku Imperial University 192716

(2) 工策㸚術者のための応用数学上 H.W.レディック 毛細管現象曲線

F.M. ミラー 